〈書 評〉

\section{岡部 守著}

\section{『土地利用調整と改良事業』}

\author{
〈2001 年 11 月・日本経済評論社〉
}

伊庭治彦

本書は，農業の外部効果である公益的機能を持続的 に確保するための議論に関して, 新たな分野に切り込 んだ一冊である。議論されるのは，地域社会が農業の 外部効果を維持し継続的に享受するためには農地打よ び土地改良施設が生産と生活の両面で活用されること （本書に従えば「高度利用」，「多目的利用」という）が 必要であること，その費用負担構造を社会的に効率化 すること，そして，それらは外部効果の計測が困難で あることを十分考慮した上での検討が必要であるこ と、である。これまでの土地改良事業に関する批判は, 地域の実情に合わない一律的な事業や施設のデザイン による非効率が主であった，これに対して本書は，土 地改良施設の高度利用という新たな視点において, 費 用負担のあり方を視点に社会的な非効率を問題とす る.

農業が，その外部効果を含名社会的に適正な産業 規模を実現することは困難である。なぜなら，そのた めに必要となる追加的な費用が農業者に補償されるこ とが必要であるが，そのような費用負担構造を実現す ることは甚だ困難だからである。このことは農業の外 部効果である公益的機能の性質自体に帰因する古くて 新しい問題であるが，あらためて検討することの意義 は大きい，本書が指摘するように，農業の公益的機能 の重要性や必要性が周知であっても，個々の農業経営 が住環境等への外部効果の維持を目的として追加的に 負担できる費用の限度が低下しており，我が国の農業 の規模はその公益的機能とは無関係に年々縮小してい るからである。

本書は次のとおり 2 部構成である.

第 I 部 土地利用調整論

第 1 章 煵場整備事業と土地利用調整一事業と

農・工間土地量調整の一体化

第 2 章 土地利用調整をめぐる各地の事例

第 II 部 土地改良事業論

第 3 章 土地改良事業の新しい方向性
第 4 章 土地改良事業の効果論

第 I 部では，農地や土地改良施設の高度利用に関す る理論的基礎を現実の土地利用調整の中から導出する ために，事例の分析に紙幅を割く。

第 1 章では， 3 つの視点（農地の賦存状況，土地利 用調整をめぐる既存研究，制度的展開）に上る分析か ら土地利用調整の機能の変遷を確認する。 その上で, 土地改良事業を，事業目的を基準に 4 期に区分し今後 の農地利用の方向を展望する。すなおち，第 1 期耕地 の外延的拡大期, 第 2 期省力効果期, 第 3 期地域開発 機能期，第 4 期土地利用調整機能期と区分し，この延 長線上に「農地と非農用地の土地利用調整」および「生 産と生活の両面での高度利用」の必要性を展望する. その結果, 2 種類の土地利用調整（「農用地間の農民に よる調整」と「農用地と非農用地間の農・工間土地利 用調整」）を一体的に行うことが必要とする.

第 2 章では，表題のと扔り事例分析をとおして第 1 章での整理を具体的な現場の動きにおいて確認する. 先に示された 2 種の土地利用調整である「農用地間の 農民による調整」と「農用地と非農用地間の農・工間 土地利用調整」に関して，それぞれ二つの効率性を検 討し第 II 部への準備を整える。一つは地域農業の合理 化に向けた土地利用とそのための基盤整備という物理 的な効率性であり，もう一つはこれらを実施するため の合意形成過程の効率性である.

第II 部では農地や土地改良施設の高度利用を行うた めの土地改良事業に関して, 事業の性格や実施上の制 約条件, 農業生産と地域環境整備に与える効果やその 評価方法等を視点として検討される。

第 3 章では，ため池や用・排水路とそこを流れる用 水自体を分析対象に, これら土地改良施設の整備事業 を, 農林業生産と地域環境整備の両面に扔いて評価し, 施設の高度利用の方法と費用負担のあり方を検討す る. 本章で特徴的なのは, 土地改良施設に関わっての 非農家や都市サイドのフリーライダー問題の提起であ る. 土地改良事業の実施には農家の投資行為が伴うが 故に, 農業の公益性に関わってのフリーライダー問題 がより身近な不公平として，また社会的な非効率とし て検討される。

第 4 章では，第 3 章に扔ける指摘，主張を裏付ける ため, 土地改良事業の効果を視点としての理論的検証 がなされる。効果の理論的整理と費用発生構造, さら には, 効果の評価方法の検討を行う。これまでの事業 の評価方法を整理しつつ, さらに事後評価の論点を提 示することにより，土地改良事業の目的構造を転換す ることの主張に理論的基礎を与えている.

本書では，以上に概観した内容において議論をすす め, これまでの土地改良事業と土地利用調整との関係 
を確認しつつ, 施設の高度利用と費用負担のあり方を 視点に現状の問題点を指摘する. とくに，論考を進め た帰結として示される事業の目的構造の転換の必要性 は時宜を得た主張であり, 社会的貢献は大きい.

そこで, 本書を出発点としてさらに議論を進めるこ とを本稿の役割とし, 第 3 章に関わっての検討を行う こととする.

さて，一般的な理解では，一つの施設を高度利用す るためには施設の汎用性を高めるための追加的な投資 や維持管理費が発生し費用の総額は上昇するが，利用 頻度が高まり利用毎の平均費用は低下する。しかし, 公平な費用負担構造にないとき, 高度利用により負担 する費用が上昇する受益者が生じたり，社会的な非効 率が生じたりする，すなわち，フリーライダーの発生 に関連して種々の問題が生じるのである.

このような問題に対する本書のアプローチは，事業 の主目的と副目的の関係における費用負担の歪みであ る. 事業の副目的となる利用を行う受益者がフリーラ イダーとなりえるとき，主目的において利用する受益 者の費用負担が不公平なものとなる，また，施設への 投資水準も過小投資のような非効率が生じることにな る.このような主目的利用者にとっての不公平や公共 投資の非効率が，事例を用いながら指摘される.

そして，これら指摘の延長線上にあるのは，将来の 土地改良事業の論理転換である。すなわち，主目的と しての「地域環境の整備」と地域住民による費用負担, 副目的としての「農林業生産の収益の確保」と農業者 の応分の負担，という費用負担構造の下での事業実施 である。このことは，本文表 3-2 にみる 3 つの結合類 型の変遷によって示される，事業目的としての農林業 生産と地域環境整備の関係が変化することにより, 土 地改良事業の性質も変化してきたのである。そこして将 来展望として, 主目的としての地域環境整備と, 副目 的としての農林業生産の収益の確保を位置づけるので ある。

以上の検討過程において若干の不満を覚えるのは, 非効率な現状の評価である。土地改良施設が地域環境 に一定の効果を及汇している一方で, 現状の費用負担 が農家にとって不公平であることや行政の肩代わり が，簡単にセカンド・ベストとして肯定されているよ うに思われる. 現状の方式が社会的に大きな非効率を
生じさせているからこそ, 土地改良事業に関する目的 構造の転換の必要性が主張されるわけであるが，現行 の制度の下での改善をまずもって検討することが必要 であると考える，換言すれば，事業推進の障壁（例え ば，地域住民の合意形成の困難性）に関わる費用を一 定としての分析に終始し，その費用低減に関する検討 がなされていないのである.

本書が指摘するように，外部効果である公益性の財 的性質から，それを生み出すための投資額の水準と費 用負担構造のあり方は，現実には管轄省庁のへゲモ ニーの問題となる.しかし，そのことをして副次的事 業に「地域合意形成機能」を意義づけ，「こうした見地 に立てば，副次的事業がフリーライダーになることは 悪でなく, 是認されるべきであろう.」(153 頁) とす る見解には, さらなる検討の必要性を感じるのである. フリーライダーを抑制するため意思決定過程のデザイ ンが議論され，その限界を明示した上でセカンド・ベ ストとして位置づけられるべきである。例えば，事業 の実施に関わる受益地区内の非農家の費用負担の可否 については，地域社会における合意形成過程の非効率 とその改善の検討が必要となる。非農家に費用負担の 了承をとりつけるために多大な費用がかかるとしよ う. その際,「行政の肩代わり」というセカンド・ベス トが選択されるためには, 費用節約の検討が必要とな る. このような問題は, 農家と非農家を含む地域社会 の意思決定過程に扔いて, 各人のレント・シーキング を抑制するような意思決定過程のデザインが検討され 㸚ばならない(非農家が集落の農会の構成員として用・ 排水路の管理作業に出役している事例があるが, 集落 内の意思決定過程においてレント・シーキングが抑制 された結果といえる). その結果において, 非効率を含 みながらも行政の肩代わりや，農家の不公平な費用負 担の甘受が合理的であることが正当化されるのであ る.しかるに, フリーライダーはやはり, 社会的な非 効率を生じる悪でありつづけるのである.

以上, 本稿が指摘したことは, 新たに議論を要する 混住化社会の合意形成に関わる問題である. その意味 で, 本書が取り扱う領域を越えている恐机があるが, 本書を議論の出発点とするものである.

（著者：神戸大学農学部） 